\title{
Kronik Ürtiker ve Etiyolojisi
}

\author{
Dilek AZKUR
}

Kırıkkale Üniversitesi Tıp Fakültesi, Çocuk Sağlığı ve Hastalıkları Anabilim Dalı, Çocuk Alerji ve İmmünoloji Kliniği, Kıııkkale, Türkiye

Ürtiker sık görülen bir deri lezyonudur ve hayat boyu prevalansı \%15-23 olarak bildirilmiştir (1). Hastaların yarısında ürtikere anjioödem eşlik eder (2). Ürtikerin altı haftadan uzun sürmesi ve haftanın hemen her günü ortaya çıkması durumunda kronik ürtiker olarak sınıflandırlır (3). Kronik ürtiker, sıcak, soğuk, güneş ışınları gibi çeşitli fiziksel etkenlerle tetikleniyorsa kronik uyarılabilir ürtiker olarak değerlendirilir (3). Bazı hastalarda kronik uyarılabilir ürtikerin farklı tipleri bir arada görülebilir. Kronik ürtiker, toplumun \%0.5-5'ini etkilemektedir (4).

Hastaları değerlendirirken alınacak ayrıntı̈ı öykü ve fizik muayene hem tanı hem de yapılacak laboratuvar tetkiklerini planlamak için yol gösterici olacaktır. Başta erişkinlerde olmak üzere kronik ürtiker etiyolojisinde çok farklı etkenler araştııımış olmakla birlikte hastaların \%50'sinde altta yatan neden bulunamamaktadır. Tanısal testler ayıııcı tanı, hastalık aktivitesinin değerlendirimesi ve uyaranları/altta yatan nedenlerin aydınlatılması amacıyla yapılmaktadır. Farklı çalışmalarda fonksiyonel oto-antikorlar, ilaçlara ve besinlere karşı gelişen psödo-alerji (alerjik olmayan hipersensitivite reaksiyonları), akut ve kronik enfeksiyonlar (Helicobacter pylori veya paraziter enfeksiyonlar) ve ağır sistemik hastalıklar gibi çeşitli faktörler kronik ürtiker nedeni olarak bildirilmiştir (3).

Derginin bu sayısında yayımlanan Arıkoğlu ve ark.nın (5) çalışmasında kronik ürtiker tanısı ile izlenen 18 yaşın altındaki 80 hastanın dosyaları retrospektif olarak değerlendirimiş. Hastaların \%53.7'sinde kronik uyarıabilir ürtiker, \%46.3'ünde kronik spontan ürtiker tespit edilmiş, etiyolojiye yönelik yapılan tetkiklerinde hastaların \%23.7'sinde atopi, \%16.4'ünde Helicobacter pylori pozitifliği, \%20.3'ünde tiroid otoantikor varlığı, \%33'ünde antinükleer antikor pozitifliği, \%25'inde gıda katkı maddesi ile ilişkili ürtiker ve \%6.7'sinde gaitada parazit saptanmış. Literatürde konuyla ilgili ülkemizden yapılan az sayıda çalışma olması nedeniyle bu makalenin ülkemizdeki duruma ışık tutması açısından okuyuculara yol gösterici olması beklenmektedir.

\section{KAYNAKLAR}

1. Mathews KP. Urticaria and angioedema. J Allergy Clin Immunol 1983;72:1-14.

2. Sanchez-Borges M, Asero R, Ansotegui IJ, Baiardini I, Bernstein JA, Canonica GW, et al. Diagnosis and treatment of urticaria and angioedema: A worldwide perspective. World Allergy Organ J 2012;5:125-47.

3. Zuberbier T, Aberer W, Asero R, Abdul Latiff AH, Baker D, Ballmer-Weber B, et al. The EAACI/GA2LEN/EDF/WAO guideline for the definition, classification, diagnosis and management of urticaria. Allergy 2018;73:1393-414.

4. Bernstein JA, Lang DM, Khan DA, Abdul Latiff AH, Baker D, Ballmer-Weber B, et al. The diagnosis and management of acute and chronic urticaria: 2014 update. J Allergy Clin Immunol 2014;133:1270-7.

5. Arıkoğlu T, Aydoğdu A, Batmaz SB, Tezol Ö, Kuyucu S. Çocukluk çağındaki kronik ürtikerli olguların etiyolojik açıdan değerlendirilmesi. Türkiye Çocuk Hast Derg 2018;4:251-7. 